\title{
Skin Squamous Cell Carcinoma or Other Skin Carcinomas pN2a TNM Finding v7
}

National Cancer Institute

\section{Source}

National Cancer Institute. Skin Squamous Cell Carcinoma or Other Skin Carcinomas pN2a

TNM Finding v7. NCI Thesaurus. Code C88487.

Skin squamous cell carcinoma or other skin carcinomas with metastasis in a single ipsilateral lymph node, more than $3 \mathrm{~cm}$ but not more than $6 \mathrm{~cm}$ in greatest dimension. (from AJCC 7th Ed.) 